\title{
Jurist-Diction
}

Volume 4 No. 5 September 202

\section{Pendekatan Keadilan Restoratif dalam Penanganan Tindak Pidana Pencurian yang Dilakukan oleh Anak}

\author{
Nurfa Caesarini Putri \\ www.nurfacaesap@yahoo.com \\ Universitas Airlangga
}

\begin{abstract}
How to cite:
Nurfa Caesarini Putri,

'Pendekatan Keadilan

Restoratif dalam Penanganan

Tindak Pidana Pencurian yang

Dilakukan oleh Anak' (2021)

Vol. 4 No. 5 Jurist-Diction.
\end{abstract}

Histori artikel:

Submit 9 Juli 2021;

Diterima 15 Agustus 2021;

Diterbitkan 1 September 2021

DOI:

10.20473/jd.v4i5.29825

p-ISSN: 2721-8392

e-ISSN: $2655-8297$

\begin{abstract}
This study aims to analize the tendency of judgment on the ruling court sentence in the case of a prison sentence which is considered still not based on restorative justice approaches as set in the Children's Criminal Justice system Act. This study discusses the imposition of prison criminal in children who commit criminal acts of theft. This research is considered important because the child's opportunities to grow and develop reasonably Despite committing a crime without being sentenced or affected in prisonization. Since the restorative justice conceptually contains the idea and principle of establishing mutual participation between children, victims, and community To complete a criminal offence. Encouraging children to be responsible for victims or the crime that have caused injuries or losses to victims, As well as establishing responsibility for not repeating any criminal deeds ever undertaken. The concept of restorative justice also puts criminal acts not primarily as a form of violation of the law, But rather as a violation by someone (a group of people) against a person.

Keywords: Restorative Justice; Judgment On The Ruling Court; Crime.
\end{abstract}

\begin{abstract}
Abstrak
Penelitian ini bertujuan untuk menganalisa kecenderungan pertimbangan Putusan Pengadilan dalam memutus pidana penjara yang dianggap masih belum berlandaskan dengan pendekatan keadilan restoratif sebagaimana diatur dalam Undang-Undang Sistem Peradilan Pidana Anak. Penelitian ini membahas mengenai pengenaan pidana penjara pada anak yang melakukan tindak pidana pencurian. Penelitian ini dianggap penting karena peneliti melihat masih terbukanya peluang anak untuk tumbuh dan berkembang secara wajar walaupun telah melakukan suatu kejahatan tanpa harus dipidana maupun terkena dampak prisonisasi. Karena secara konseptual keadilan restoratif berisi gagasan dan prinsip yaitu membangun partisipasi bersama antara anak, korban, serta kelompok masyarakat untuk menyelesaikan suatu peristiwa atau tindak pidana. Mendorong anak bertanggung jawab terhadap korban atau peristiwa atau tindak pidana yang telah menimbulkan cedera atau kerugian terhadap korban, serta membangun tanggung jawab untuk tidak mengulang lagi perbuatan pidana yang pernah dilakukan. Konsep keadilan restoratif juga menempatkan peristiwa atau tindak pidana tidak terutama sebagai suatu bentuk pelanggaran hukum, melainkan sebagai pelanggaran oleh seseorang (sekelompok orang) terhadap orang (sekelompok orang).

Kata Kunci: Keadilan Restoratif; Pertimbangan Putusan Pengadilan; Perbuatan Pidana.
\end{abstract}




\section{Pendahuluan}

Kejahatan yang dilakukan oleh anak meliputi tindakan - tindakan yang sering menimbulkan kekhawatiran di lingkungan keluarga, sekolah maupun masyarakat, contoh tindak kejahatan yang sering dilakukan oleh anak dan yang akan dibahas dalam skripsi ini adalah pencurian. Kebanyakan pelaku tindak pidana yang telah dewasa umumnya sudah melakukan tindak kejahatan sejak menjadi anak. Sebab seorang anak melakukan tindakan kejahatan umumnya belum terlihat jika tidak diselidiki atau adanya lingkungan yang sangat buruk. ${ }^{1}$

Keadilan restoratif adalah konsep pemidanaan, namun sebagai konsep pemidananaan tidak hanya terbatas pada ketentuan hukum pidana (formal dan materiil). Keadilan restoratif berbeda dengan keadilan retributif ${ }^{2}$ yang dianut sistem peradilan pidana sekarang. Perbedaan itu antara lain terdapat dalam beberapa hal, yaitu: pertama, melihat tindakan kriminal secara komprehensif. Tidak saja mendefinisikan kejahatan sebagai pelanggaran hukum semata, namun juga memahami bahwa pelaku merugikan korban, masyarakat dan bahkan dirinya sendiri. Kedua, melibatkan banyak pihak dalam merespon kejahatan, tidak hanya sebatas urusan pemerintah dan pelaku kejahatan, namun juga korban dan masyarakat. Ketiga, mengukur kesuksesan dengan cara yang berbeda, tidak hanya dari seberapa besar hukuman dijatuhkan, namun juga mengukur seberapa kerugian dapat dipulihkan atau dicegah.

Bagir Manan mengemukakan bahwa secara konseptual keadilan restoratif berisi gagasan dan prinsip yaitu membangun partisipasi bersama antara pelaku, korban, serta kelompok masyarakat untuk menyelesaikan suatu peristiwa atau tindak pidana. ${ }^{3}$ Menempatkan pelaku, korban, dan masyarakat sebagai stakeholder yang bekerja bersama dan langsung berusaha menemukan penyelesian yang dipandang adil bagi semua pihak. Mendorong pelaku bertanggung jawab

\footnotetext{
${ }^{1}$ Abintoro Prakorso, Kriminologi Dan Hukum Pidana (LaksBang PRESSindo 2017).[196].

${ }^{2}$ Rena Yulia, 'penerapan keadilan restoratif dalam putusan hakim: upaya penyelesaian konflik melalui sistem peradilan pidanaisẸpikajian putusan ma nomor 653/k/pid/2011' (2012) 5 Jurnal

${ }^{3}$ R Wiyono, Sistem Peradilan Pidana Anak Di Indonesia (Sinar Grafika 2019).[39].
} Yudisial.[233]. 
terhadap korban atau peristiwa atau tindak pidana yang telah menimbulkan cedera atau kerugian terhadap korban, serta membangun tanggung jawab untuk tidak mengulang lagi perbuatan pidana yang pernah dilakukan. Konsep keadilan restoratif juga menempatkan peristiwa atau tindak pidana tidak terutama sebagai suatu bentuk pelanggaran hukum, melainkan sebagai pelanggaran oleh seseorang (sekelompok orang) terhadap orang (sekelompok orang). Dengan demikian, pelaku diarahkan pada pertanggungjawaban terhadap korban bukan mengutamakan pertanggungjawaban hukum.

Nampaknya, lembaga penegak hukum melupakan maksud dari adanya keadilan restoratif karena keadilan restoratif tidak hanya diselesaikan melalui proses diversi. Namun, Majelis hakim juga harus mempertimbangkan kondisi seorang anak jika dalam kasus pencurian yang dilakukan oleh anak, putusan yang akan diberikan adalah berupa penjara. Mengingat tujuan keadilan restoratif itu sendiri adalah dengan mewujudkan kesejahteraan anak dan menghindarkan anak dari perampasan kemerdekaan dan tujuan lainnya. Karena hal ini, tentu melanggar maksud dari keadilan restoratif itu sendiri.

\section{Pengaturan Keadilan Restoratif dalam UU SPPA}

Berdasarkan Pasal 1 angka 6 Undang-Undang Nomor 11 Tahun 2012 tentang SPPA(selanjutnya disingkat UU SPPA), Keadilan Restoratif adalah penyelesaian perkara tindak pidana dengan melibatkan pelaku, korban, keluarga pelaku/korban, dan pihak lain yang terkait untuk bersama-sama mencari penyelesaian yang adil dengan menekankan pemulihan kembali pada keadaan semula, dan bukan pembalasan. Di dalam UU SPPA tidak ada ketentuan yang dapat menjelaskan lebih lanjut apa yang dimaksud dengan "keadilan restoratif", kecuali dalam penjelasan umum UU SPPA yang menyatakan ${ }^{4}$ Keadilan restoratif merupakan suatu proses diversi. Namun sebenarnya, jika dilihat lebih dalam keadilan restoratif bukan hanya sebatas terhadap suatu proses diversi. Karena jika menitikberatkan pada 
proses diversi maka, jika diversi dikatakan gagal tidak akan ada proses pidana berkelanjutan yang akan memperjuangkan sisi keadilan anak.

Menurut penulis keadilan restoratif adalah suatu bentuk penyelesaian perkara tindak pidana yang melibatkan semua pihak termasuk di dalamnya penegak hukum (polisi, jaksa, hakim) untuk bersama-sama mencari penyelesaian serta menciptakan penyelesaian perkara pidana dengan adil dan mengedepankan kepentingan terbaik untuk anak. Yang termasuk kepentingan anak dalam hal ini meliputi, masa depan anak itu sendiri, labelling yang diberikan masyarakat, sikap traumatis yang dapat ditimbulkan dari proses berperkara itu sendiri. Keadilan Restoratif bukanlah proses penyelesaian perkara pidana seperti pada Peradilan Umum, karena keadilan restoratif bersifat memulihkan/mencegah bukan untuk memberikan efek jera kepada anak.

\section{Pengaturan Keadilan Restoratif dalam CRC}

Pembentukan program keadilan restoratif didasari oleh standar internasional yang signifikan tentang perlindungan hak-hak anak yang terlibat dalam sistem peradilan pidana. Pasal 35 CRC mengakui bahwa hak setiap anak yang diduga atau diakui melanggar hukum pidana harus diperlakukan sejalan dengan harkat dan martabat dan nilai dari anak dengan tujuan untuk memperkuat pandangan anak tentang HAM dan kebebasan mendasar orang lain, dengan mempertimbangkan usianya dan keinginan untuk meningkatkan reintegrasi sosialnya serta asumsi tentang peran konstruktifnya di dalam masyarakat (Pasal 40 ayat (1) CRC). Dalam programnya, CRC mendorong pembentukan peradilan yang terpisah yang berlaku khusus untuk anak (Pasal 40 ayat (3) CRC) $)^{5}$.

Selain itu, keadilan restoratif dapat diadaptasi untuk memenuhi persyaratan khusus anak dan juga untuk untuk mencerminkan konteks sosial dan budaya yang berbeda karena keadilan restoratif memiliki potensi untuk melindungi kepentingan yang terbaik untuk anak melalui berbagai tahapan prosedur, bukan hanya diversi saja. Inti dari konsep keadilan restoratif adalah memulihkan

\footnotetext{
${ }^{5}$ Office of The Special Representative of The Secretary-General on VAC, Promoting Restorative Justice For Children (United Nation 2016).[4].
} 
kerusakan yang diakibatkan oleh suatu faktor, bukan hanya menghukum suatu bentuk kejahatan. Indonesia perlu mengadopsi model-model keadilan restoratif ini terhadap UU SPPA.

Salah satunya ada VOM, dalam VOM anak yang diduga melakukan tindak pidana dan korban secara sendiri-sendiri dipertemukan dalam pra-mediasi oleh fasilitator untuk menentukan masalah apa yang akan dibahas selama VOM. Setelah itu para pihak masuk ke dalam proses mediasi dimana para pihak dipertemukan untuk berdiskusi dibantu dengan mediator yang ahli dalam bidang tersebut. Fungsi mediator disini diharapkan guna menyamakan kedudukan hukum antara anak dan korban, karena bagaimanapun anak yang melakukan tindak pidana rentan diperlakukan secara adil selama proses penyelesaian. Mediasi VOM berbeda dengan diversi yang hanya mengandalkan musyawarah antara kedua pihak dan pihak lainnya. Mediasi dalam VOM memungkinkan anak dan korban untuk mencapai kesepakatan dan mengganti kerugian yang telah ditimbulkan.

Tentu saja mediasi ini tak lepas dari model circle sentencing yang di dalam menyelesaikan perkara didasarkan dengan konsep saling memaafkan dan tanggung jawab. Korban diharapkan untuk memaafkan tindakan yang telah dilakukan oleh anak dan anak diharapkan untuk bertanggung jawab sesuai dengan apa yang telah disepakati bersama. Partisipasi masyarakat juga diperlukan guna mendukung keberhasilan pendekatan keadilan restoratif disini. Seperti yang dilakukan oleh Dewan Reparatif Komunitas bisa melakukan suatu bentuk pengawasan terhadap anak yang telah melakukan tindak pidana. Dewan Reparatif Komunitas kemudian dapat menyerahkan hasil laporan pengawasan tersebut kepada Pengadilan, dengan adanya dewan ini diharapkan dapat mempertegas konteks partisipasi masyarakat dan mengurangi kesempatan anak untuk dirampas kemerdekaannya.

\section{Jaminan Hak-Hak Anak}

Dalam penelitian ini penulis akan mencantumkan 4 Pengaturan yang dirasa perlu untuk menunjang hak-hak anak dalam rangka penanganan perkara dengan pendekatan keadilan restoratif yaitu: 
1. Jaminan Hak-Hak Anak yang Diatur Dalam Convention On The Rights Of The Child.

CRC mengemukakan beberapa prinsip-prinsip dasar untuk melindungi anak yang berhadapan dengan hukum: ${ }^{6}$

a) Perlakuan yang konsisten dalam menjaga harkat dan martabat pada anak. Prinsip dasar ini sesuai dengan pasal 1 Universal Declaration of Human Rights (selanjutnya disingkat UDHR), yang menetapkan bahwa semua orang dilahirkan bebas dan setara dalam segala hak. Hak yang melekat pada harkat dan martabat seseorang inilah yang menjadi acuan CRC untuk menghormati dan melindungi anak dari seluruh proses mulai dari kontak pertama anak dengan penegak hukum sampai pada implementasi;

b) Perlakuan yang kepada anak pentingnya hak asasi manusia dan menghargai sesama. Prinsip ini sejalan dengan pertimbangan dalam pembukaan CRC terkait dengan anak harus dibesarkan dengan semangat dan cita-cita yang terkandung dalam Charter of United Nation. Ini juga berarti bahwa, dalam sistem peradilan anak, perlakuan dan pendidikan anak-anak harus diarahkan pada pengembangan penghormatan terhadap hak asasi manusia dan kebebasan (Pasal 29 ayat (1) huruf (b) CRC dan komentar umum No. 1 tentang tujuan pendidikan). Jelas bahwa prinsip peradilan anak ini menuntut penghormatan penuh dan implementasi jaminan untuk peradilan yang adil yang diakui dalam Pasal 40 (2) CRC, karena jika penegak hukum seperti jaksa, polisi, dan hakim tidak sepeneuhnya menghormati dan melindungi jaminan ini, bagaimana bisa seorang anak mencontoh sikap pengajaran tersebut untuk menghormati hak asasi manusia lain sedangkan hak asasinya terganggu?; ${ }^{7}$

c) Perlakuan yang memperhitungkan usia anak dan mendorong re-integrasi anak serta mengasumsikan peran konstruktif pada masyarakat. Prinsip ini harus diterapkan, diobservasi, dan dihormati dalam penyelesaian perkara tindak pidana yang dilakukan oleh anak. Ini mensyaratkan bahwa semua penegak hukum yang berada dalam peradilan pidana anak memiliki pengetahuan tentang perkembangan anak, pertumbuhan anak yang dinamis dan berkelanjutan, apa yang sepatutnya layak untuk kehidupan mereka, dan berbagai bentuk kekerasan terhadap anak;

d) Penghormatan terhadap martabat anak mengharuskan semua bentuk kekerasan dalam perlakuan terhadap anak-anak yang berkonflik dengan hukum harus dilarang dan dicegah. Laporan yang diterima oleh Komite menunjukkan bahwa kekerasan terjadi di semua fase proses peradilan anak, dari kontak pertama dengan polisi, selama penahanan praperadilan dan

${ }^{6}$ Committee On The Rights Of The Child, 'Children's Right In Juvenile Justice' (United Nations 2007) <https://www2.ohchr.org/english/bodies/crc/docs/CRC.C.GC.10.pdf> accesed 6 November 2019.

${ }^{7}$ ibid. 
selama tinggal dalam perawatan dan fasilitas lainnya untuk anak-anak yang dihukum karena dirampas kebebasannya. Komite mendesak Negara-negara Pihak untuk mengambil langkah-langkah efektif untuk mencegah kekerasan semacam itu dan untuk memastikan bahwa para pelakunya diadili dan untuk memberikan tindak lanjut yang efektif atas rekomendasi yang dibuat dalam laporan United Nations Study on Violence Against Children presented to the General Assembly in October $2006 .^{8}$

2. Jaminan Hak-Hak Anak Dalam UU No. 4 Tahun 1979 Tentang Kesejahteraan Anak.

Berdasarkan Pasal 2 sampai Pasal 8 UU Kesejahteraan Anak dapat diketahui terdapat 10 hak-hak anak yang diatur dalam UU Kesejahteraan Anak, yaitu: ${ }^{9}$

a) Anak berhak atas kesejahteraan, perawatan, asuhan dan bimbingan berdasarkan kasih sayang baik dalam keluarga maupun dalam asuhan khusus;

b) Anak berhak atas pelayanan untuk mengembangkan kemampuan dan kehidupan sosialnya;

c) Anak berhak atas pemeliharaan dan perlindungan, baik semasa dalam kandungan maupun sesudah dilahirkan;

d) Anak berhak atas perlindungan terhadap lingkungan hidup yang dapat membahayakan atau menghambat pertumbuhan dan perkembangan anak dengan wajar;

e) Dalam keadaan yang membahayakan, anaklah yang pertama berhak mendapat pertolongan, bantuan, dan perlindungan;

f) Anak yang tidak mempunyai orang tua berhak memperoleh asuhan oleh negara atau orang atau badan;

g) Anak yang tidak mampu berhak memperoleh bantuan agar dalam lingkungan keluarganya dapat tumbuh dan berkembang dengan wajar;

h) Anak yang mengalami masalah kelakuan diberi pelayanan dan asuhan yang bertujuan menolongnya guna mengatasi hambatan yang terjadi dalam masa pertumbuhan dan perkembangan dan juga diberikan kepada anak yang telah dinyatakan bersalah melakukan pelanggaran hukum berdasarkan keputusan hakim;

i) Anak cacat berhak memperoleh pelayanan khusus untuk mencapai tingkat pertumbuhan dan perkembangan sejauh batas kemampuan dan kesanggupan anak yang bersangkutan;

j) Bantuan dan pelayanan, yang bertujuan mewujudkan kesejahteraan anak menjadi hak setiap anak tanpa membedakan jenis kelamin, agama, pendirian politik, dan kedudukan sosial.

\footnotetext{
${ }^{8}$ ibid.

${ }^{9}$ Mohammad Taufik Makarao [et.,al.], Hukum Perlindungan Anak dan Penghapusan Kekerasan dalam Rumah Tangga (PT Rineka Cipta 2014).[18].
} 
3. Jaminan Hak-Hak Anak dalam UU No. 39 Tahun 1999 Tentang Hak Asasi Manusia

Jaminan anak yang berhadapan dengan hukum ditegaskan dalam Pasal 66 UU HAM, yaitu:

a) Setiap anak berhak untuk tidak dijadikan sasaran penganiayaan, penyiksaan, atau penjatuhan hukuman yang tidak manusiawi;

b) Hukuman mati atau seumur hidup tidak dapat dijatuhkan untuk pelaku tindak pidana yang masih anak;

c) Setiap anak berhak untuk tidak dirampas kebebasannya secara melawan hukum;

d) Penangkapan, penahanan, atau pidana penjara anak hanya boleh dilakukan sesuai dengan hukum yang berlaku dan hanya dapat dilaksanakan dengan upaya terakhir;

e) Setiap anak yang dirampas kebebasannya berhak mendapatkan perlakuan secara manusiawi dan dengan memperhatikan kebutuhan pengembangan pribadi sesuai dengan usianya dan harus dipisahkan dari orang dewasa, kecuali demi kepentingannya;

f) Setiap anak yang dirampas kebebasannya berhak mendapatkan bantuan hukum atau bantuan lainnya secara efektif dalam setiap tahapan upaya hukum yang berlaku;

g) Setiap anak yang dirampas kebebasannya berhak untuk membela diri dan memperoleh keadilan di depan Pengadilan Anak yang obyektif dan tidak memihak dalam sidang yang tertutup.

4. Jaminan Hak-Hak Anak Dalam UU Mo. 23 Tahun 2002 Jo. UU No. 35 Tahun 2014 Tentang Perlindungan Anak.

Dalam Pasal 25 UUPA disebutkan bahwa, "Kewajiban dan tanggung jawab masyarakat terhadap perlindungan anak dilaksanakan melalui kegiatan peran masyarakat dalam penyelenggaraan perlindungan anak". Ketentuan Pasal 72 ayat (2) UUPA menyebutkan bahwa peran masyarakat dilakukan oleh orang perseorangan, lembaga perlindungan anak, lembaga sosial kemasyarakatan, lembaga swadaya masyarakat, lembaga pendidikan, lembaga keagamaan, badan usaha, dan media masa. Pasal 26 UUPA mengatur mengenai kewajiban dan tanggung jawab keluarga dan orang tua, yaitu:

1. Mengasuh, memelihara, mendidik, dan melindungi anak;

2. Menumbuhkembangkan anak sesuai dengan kemampuan anak, bakan dan minatnya;

3. Mencegah terjadinya perkawinan pada usia anak-anak; 
4. Memberikan pendidikan karakter dan penanaman budi pekerti pada anak. Penyelenggaraan perlindungan Undang-Undang tentang Perlindungan Anak. Perlindungan terhadap anak diselenggarakan dalam bidang agama, kesehatan, pendidikan, sosial, serta perlindungan khusus kepada anak yang tercantum pada Pasal 59 angka 2 UUPA.

\section{Pidana Penjara dalam Sistem Peradilan Pidana Anak}

Pidana Penjara merupakan salah satu jenis pidana yang terdapat dalam sistem peradilan pidana anak, sebagaimana tercantum dalam pasal 71 ayat (1) UU SPPA bahwa pidana pokok bagi anak sebagai berikut: ${ }^{10}$

a) Pidana Peringatan berdasarkan pada Pasal 72 UU SPPA;

b) Pelatihan Kerja berdasarkan penjelasan pada Pasal 78 ayat (1) UU SPPA;

c) Pembinaan dalam Lembaga berdasarkan pidana pembinaan dalam lembaga dilakukan di tempat pelatihan kerja atau lembaga yang diselenggarakan, baik oleh pemerintah maupun swasta. Pidana pembinaan ini dijatuhkan apabila keadaan dan perbuatan anak tidak membahayakan masyarakat;

d) Penjara berdasarkan pada Pasal 79 ayat (1) UU SPPA.

Pada Bab V UU SPPA menyebutkan tentang sanksi pidana dan sanksi tindakan. ${ }^{11}$ Sehingga, dapat dikatakan bahwa UU SPPA menganut sistem sanksi Double track system dimana jenis sanksi yang digunakan ada (2) yaitu sanksi pidana dan sanksi tindakan. Sanksi tindakan sendiri adalah apa yang dibebankan kepada orang yang melakukan tindak pidana bukan merupakan penderitaan. Sudarto mengemukakan bahwa pidana dimaksudkan sebagai pembalasan atau pengimbalan terhadap kesalahan pelaku, sedangkan tindakan dimaksudkan untuk perlindungan masyarakat terhadap orang yang melakukan perbuatan yang membahayakan masyarakat dan untuk pembinaan dan perawatan pelaku.

Secara dogmatik, pidana dikenakan kepada orang yang normal jiwanya dan mampu untuk bertangung jawab. Orang yang tidak mampu bertanggung jawab tidak boleh dipidana. Terhadap orang yang melakukan tindak pidana tersedia tindakan yang dapat dikenakan kepadanya. Namun menurut peneliti, double track system sendiri masih bermakna kabur. Karena jika dimisalkan,pidana

\footnotetext{
${ }^{10}$ R. Wiyono, Op.Cit.[141].

${ }^{11}$ ibid.[144].
} 
penjara yang dikenakan terhadap anak dilaksanakan di lembaga pemasyarakatan, jadi pidana penjara dalam konteks ini merupakan sanksi pidana atau tindakan? Mengingat sanksi pidana adalah untuk memberikan efek jera dan sanksi tindakan itu untuk memberikan perlindungan tersendiri kepada anak. Peneliti merasa bahwa pidana penjara dalam lembaga pemasyarakatan ini bisa jadi dengan tujuan untuk perlindungan, sehingga dapat disebut pidana penjara dalam konteks ini merupakan sanksi tindakan. Namun, baik penjara maupun lembaga pemasyarakatan sama-sama memiliki efek negatif pada tumbuh kembang anak. Salah satunya adalah prisonisasi dan sikap yang dapat cenderung mengulang lagi tindakannya di lain waktu.

Donald Clemmer" adalah pengemuka istilah terminologi "prisonization" atau disebut prisonisasi. Istilah tersebut menunjuk pada proses asimilasi narapidana -yang pada konteks penelitian ini adalah anak- ke subkultur narapidana baik pandangan, norma, kebiasaaan, dan budaya umum lainnya yang sudah ada dalam Lembaga Pemasyarakatan (LAPAS). Hal ini terjadi karena adanya proses ketika narapidana baru secara kelembagaan akan menerima gaya hidup dan nilai-nilai yang sudah ada dalam LAPAS. ${ }^{13}$ Prisonisasi ini akhirnya membentuk semacam kode khusus di lingkungan narapidana secara informal. Semua sikap dan tingkah laku ini diperoleh melalui proses belajar dengan sesama anak yang ada di dalam LAPAS dalam waktu yang relatif lama. Karena itu, secara teoritis, anak yang sudah mengalami internalisasi sikap dan perilaku dari gaya hidup jahat sangat mungkin melanjutkan karir kejahatannya, dan kecil kemungkinannya untuk berhenti melakukan tindak kejahatan.

\section{Pembahasan Putusan Pengadilan}

Untuk menunjang penelitian ini, maka peneliti akan menjabarkan beberapa putusan pengadilan dan menganalisa pertimbangan apa yang diberikan oleh pengadilan terhadap terdakwa yang akan membantu peneliti untuk memberikan alternatif atau analisa yang sesuai dengan pendekatan keadilan restoratif yang seharusnya. Berikut adalah Putusan No. 16/Pid. Sus. Anak/2015/PN. Pdg.

\footnotetext{
${ }^{12}$ Widodo, Op.Cit.[6].

${ }^{13}$ ibid. [8].
} 


\section{a. Duduk Perkara}

Pada hari Rabu tanggal 21 Mei 2014 sekitar antara pukul 21.00 Wib sampai dengan pukul 09.00 Wib bertempat di rumah kosnya J1. Aru Indah No.6 Kel. Lubuk Begalung Kec. Lubuk Begalung Kota Padang telah kehilangan 1 (satu) unit sepeda motor jenis Yamaha Mio BA 2996 ND, bahwa yang terakhir memarkirkan motor saksi korban diteras rumah kos saksi adalah anak ibu kos, stang dalam keadaan terkunci dan kuncinya dipegang oleh ibu kos saksi, bahwa berdasarkan keterangan tetangga kos saksi sewaktu ia pergi shalat subuh, motor saksi masih terparkir di teras rumah kos saksi.

\section{b. Pertimbangan Pengadilan}

Anak telah didakwa dengan oleh Penuntut Umum dengan dakwaan tunggal yaitu pasal 363 ayat (1) ke-4 KUHP jo. UU SPPA yang unsur-unsurnya sebagai berikut:

1) Unsur "Barangsiapa".

Penuntut umum telah menghadapkan para Anak ke muka persidangan berdasarkan keterangan saksi-saksi dan dapat disimpulkan bahwa orang yang dihadapkan di persidangan ini adalah Anak I dan Anak II sesuai identitas dalam surat dakwaan. Dengan demikian menurut Penuntut umum tidak terjadi kekeliruan orang yang dihadapkan di persidangan ini dan dengan demikin maka unsur ini terpenuhi.

2) Unsur "Mengambil barang sesuatu yang seluruhnya atau sebagian kepunyaan orang lain".

Anak dalam persidangan telah membantah bahwa mereka tidak pernah mengambil sepeda motor pada waktu dan ditempat kejadian tersebut namun akhirnya anak memberikan keterangan palsu karena takut terhadap polisi yang telah berkali-kali menanyakan pengakuan anak dan menginterogasi anak. Saksi yang diajukan oleh penuntut umum sebenarnya juga tidak mengetahui siapa yang mengambil sepeda motor korban. Sehingga BAP para anak tidak dapat dijadikan sebagai bukti petunjuk. Sehingga berdasarkan pertimbangan tersebut diatas unsur ke-2 ini tidak terpenuhi 
dalam perbuatan Anak, karena tidak didukung dua alat bukti yang sah, berdasarkan ketentuan pasal 183 KUHAP. Oleh karena salah satu unsur dari Pasal 363 ayat (1) ke-4 KUHP Jo. UU SPPA tidak terpenuhi, maka para Anak haruslah dinyatakan tidak terbukti secara sah dan meyakinkan melakukan tindak pidana sebagaimana didakwakan dalam dakwaan tunggal Penuntut Umum, sehingga para Anak haruslah dibebaskan dari dakwaan tersebut dan hak-hak anak haruslah dipulihkan dalam kemampuan, kedudukan, harkat serta martabatnya.

\section{c. Analisa Putusan}

Seharusnya dalam pemeriksaan oleh penyidik juga dihadirkan Pembimbing Kemasyarakatan untuk memberikan pandangannya atau sarannya dan tidak memberatkan posisi anak. Menciptakan rasa takut supaya anak mengakui perbuatannya sangat bertentangan dengan pendekatan keadilan restoratif, sedangkan pendekatan keadilan restorative sendiri sangat menjunjung tinggi harkat dan martabat anak dan menentang segala bentuk diskriminasi. Disebutkan pada pasal 58 angka 1 UU HAM yaitu setiap anak berhak untuk mendapatkan perlindungan hukum dari segala bentuk kekerasan fisik atau mental, penelantaran, perlakuan buruk, dan pelecehan seksual selama dalam pengasuhan orang tua atau walinya, atau pihak lain manapun. Berdasarkan pasal diatas, peneliti menyimpulkan bahwa menciptakan rasa takut sama dengan bentuk kekerasan secara mental dan hal ini bertentangan dengan yang diatur dalam UU HAM itu sendiri. Pembuatan BAP yang sewenang-wenang juga telah menempatkan nama anak menjadi stigma negatif di masyarakat dan anak bisa dikucilkan dari lingkungannya. Maka dari itu untuk menghindari terjadi kembali kasus serupa dibutuhkan aparat penegak hukum yang mengerti filosofi dari konsep keadilan restoratif lagi. Bahwa, anak tidak dilindungi dengan 1 undang-undang saja melainkan terdapat peraturan lain yang dapat mengacu penegak hukum untuk menjatuhkan suatu tindakan terhadap anak yang berhadapan dengan hukum. 


\section{Kesimpulan}

Pertama Pendekatan keadilan restoratif dalam sistem peradilan pidana anak di Indonesia masih tidak sesuai dengan apa yang dicita-citakan dalam keadilan restoratif sesungguhnya seperti yang diatur dalam CRC. Hal ini dikarenakan keadilan restoratif dalam UU SPPA itu sendiri tidak mengatur secara berkelanjutan konteks ini selain diterangkan dalam diversi. Sistem double track sendiri masih bermakna kabur mengenai indikasi-indikasi apa saja yang dapat digolongkan sebagai sanksi pidana dengan sanksi tindakan. Hak-hak anak yang telah diatur dalam UU Kesejahteraan Anak, UU HAM, UU Perlindungan Anak masih kurang diperhatikan karena aparat cenderung berpedoman pada UU SPPA sebagai proses penyelesaian terhadap anak yang melakukan tindak pidana.

Kedua Dalam beberapa contoh kasus yang diatas, peneliti masih tidak menemukan cerminan keadilan restoratif dalam penerapan sistem peradilan pidana anak melainkan hukuman yang dikenakan oleh pengadilan masih bersifat retributif dan penegakan hukum pada tingkat penyidikan masih cenderung mendiskriminasi anak dan terjadi kekerasan mental/ psikologis yang membuat anak seolah-olah tidak dapat melakukan pembelaan atas dirinya sendiri. Penjatuhan sanksi pidana kepada anak harus didasarkan atas "keseimbangan" dan "best interest" dengan lebih mengutamakan kerugian yang dapat dipulihkan dibandingkan dengan pemberian efek jera agar anak diharapkan tidak melakukan perbuatannya lagi.

\section{Daftar Bacaan}

\section{Buku}

Abintoro Prakorso, Kriminologi Dan Hukum Pidana (LaksBang PRESSindo 2017).

Mohammad Taufik Makarao, et., al., Hukum Perlindungan Anak dan Penghapusan Kekerasan dalam Rumah Tangga (PT Rineka Cipta 2014).

R. Wiyono, Sistem Peradilan Pidana Anak Di Indonesia (Sinar Grafika 2019).

VAC, Office of The Special Representative of The Secretary-General, Promoting Restorative Justice For Children (United Nation 2016). 


\section{Perundang-undangan}

Undang-Undang Nomor 4 Tahun 1979 tentang Kesejahteraan Anak (Lembaran Negara Tahun 1979 Nomor 32, Tambahan Lembaran Negara Nomor 3143).

Undang-Undang Nomor 39 Tahun 1999 tentang Hak Asasi Manusia (Lembaran Negara Republik Indonesia Tahun 1999 Nomor 165, Tambahan Lembaran Negara Republik Indonesia Nomor 3886).

Undang-Undang Nomor 23 Tahun 2002 tentang Perlindungan Anak (Lembaran Negara Republik Indonesia Tahun 2002 Nomor 109, Tambahan Lembaran Negara Republik Indonesia Nomor 4235) Jo. Undang-Undang Nomor 35 Tahun 2014 Tentang Perlindungan Anak (Lembaran Negara Republik Indonesia Tahun 2014 Nomor 297, Tambahan Lembaran Negara Republik Indonesia Nomor 5606).

Undang-Undang Nomor 11 Tahun 2012 tentang Sistem Peradilan Pidana Anak (Lembaran Negara Republik Indonesia Tahun 2012 Nomor 153, Tambahan Lembaran Negara Republik Indonesia Nomor 5332). 